\title{
Enhance Practical Training of E-Commerce According to the National Standard Based on the Experiences of Guangdong University of Foreign Studies
}

\author{
Hongliang Wang \\ Department of E-Commerce \\ Guangdong University of Foreign Studies \\ Guangzhou, China
}

\begin{abstract}
Electronic Commerce (E-Commerce), as a typical major facing internet employment service and internet entrepreneurship, emphasizes the integration of management economics and information. And it is involved in cross-discipline knowledge and practical application. Universities should clarify their goals to set a practical teaching system scientifically for talents cultivation, which can greatly improve the quality of talent cultivation. This paper will analyze the questionnaires in order to sort out the existing problems in professional ecommerce training and therefore will put forward some construction ideas for the practical teaching system of ecommerce. Through practical training of e-commerce at Guangdong University of foreign studies, universities should enhance the professional training system, innovate teaching environment for practice, reinforce the extracurricular instructions and establish international training practice platform. These are of great importance to improve the practical training of e-commerce which could provide references for practical training system of e-commerce.
\end{abstract}

Keywords-national standards; e-commerce; professional training system

\section{INTRODUCTION}

E-commerce, as a new national strategic industry, is leading a new business model and can optimize the industry transformation and technological upgrading, which also plays great importance in improving information consumption, modern service industry and economic development of information. E-commerce has become an original power for economic development, providing a new space for mass entrepreneurship and innovation.

The major of E-commerce is an emerging field based on information technology such as the internet, facing towards diversified business activities of modern economics. It focuses on the integration of management, economics and information with an applicable characteristic in its cross-disciplinary knowledge and application and it is a typical major facing internet entrepreneurship and innovation. The practical courses of e-commerce require no less than $20 \%$ of the total credits according to the national standards referred to as the basic standards. On the basis of this standard, colleges and universities establish their own standards according to their own characteristics of running schools, teaching aims; major orientation and regional needs, but there are still many problems exiting [1].

\section{Current Situation of Practical Teaching For E- COMMERCE MAJOR}

\section{A. Lack the Integrity for Practice}

At present, the practical teaching of e-commerce class is scattered and overlapping, lacking systematic design and overall planning. What's more, based on the theoretical class even though there is a list of some practical credits, the specific contents are insufficient. The assessment of practical courses is relatively random and lack of process monitoring which is difficult for students to achieve the expected goal of practical courses and to combine theoretical knowledge with practical ability. According to the conducted questionnaire survey, some undergraduate students in their fourth year of e-commerce are unable to design a decent web page, to operate and manage an e-commerce website and to help enterprises design feasible network marketing plans according to the needs of enterprises.

\section{B. The Teachers of Practical Training can not Meet the Needs}

At present, e-commerce practice classes are delivered mostly by the teachers who are specialized in theory rather than practice. These teachers usually lack experiences working in a line of enterprise, although some colleges and universities encourage young teachers to carry out the practice in the companies, or just hire experienced staffs from the first-line into the school as lecturers, however, due to the conflict between schools and companies, working time, system differentiation, the enthusiasm of both sides and the actual effect is not very ideal.

\section{Insufficient Campus Training Rooms and off-Campus Practice Bases}

With the rapid development of artificial intelligence, the ecommerce industry has widespreadly introduced artificial intelligence. The traditional work posts are going to be 
replaced by machines, such as video production, page copywriting planning as well as the main diagram which can bring great convenience for store operation and management. The corresponding work under the environment of artificial intelligence will be gradually eliminated. But most e-commerce laboratories, teaching facilities of training rooms still greatly depend on the previous experimental environment, unable to follow the pace of technology or even meet the needs of relevant posts of e-commerce major concerning artificial intelligence, blockchain, big data technology. Most ecommerce enterprises are small and medium-sized with scattered positions and difficult to manage and there is generally a lack of large-scale internship bases.

\section{THOUGHTS ON THE CONSTRUCTION OF PRACTICAL TEACHING SYSTEM FOR E-COMMERCE MAJOR}

The construction of e-commerce practical teaching system must be from the perspective of cultivating students' vocational ability, on the basis of the post demand. They should propose a framework of application-oriented workability and determine the training goal of practical teaching, build up a practical teaching system according to the process[2]. In the environment of the new information technology, we should focus on the cultivation of English application ability and International e-commerce practical ability; insist on the combination between theory and practice, practice and society, scientific activities and scientific researches.

\section{A. Establishing Practical Teaching Objectives}

The design of the real practice education system should meet the goal of talent cultivation and is closely related to the characteristics of this major, to help the students master natural science, social science and humanities through liberal arts education[3]. What's more, we should grasp the basic theory and professional knowledge of modern managerial network economy and information technology, have a good command of the professional theory and method of e-commerce, combine the theory and practice closely in order to solve the real problem. Teachers and students are also required to be equipped with the latest information on industry development and to focus on innovation of skills and business model, acquire the related theories. Based on these, they can set up their goals of practical education, practical operation skills and quality expansion, furthermore, to confirm the combination between overall goals and sub goals[4].

\section{B. Perfecting the Real Practice Contents}

The major of e-commerce should comply with the rules between knowledge and ability, set up corresponding theories, practical skills, innovation ability and comprehensive capability according to the vocational ability of e-commerce, at the same time , it is essential to set up some basic, managerial, engineering and comprehensive modulated program in campus and off-campus ${ }^{[5]}$.

\section{Setting up a Systematic Practical Education Platform}

The construction of e-commerce practical education system should be goal-oriented, in order to meet the requirements of knowledge, ability and quality, education should reform from teaching contents, teaching methods and teaching processes. To realize the ability and quality reform, it is significant to train students' research ability, practical skills, innovative ability, at the same time, we should establish a corresponding scientific education platform, real practice education platform, operation platform and innovation platform[6].

\section{CONSTRUCTION OF PRACTICAL TEACHING SySTEM FOR E-COMMERCE MAJOR IN GDUFS}

In line with the basic idea that colleges and universities should operate by some standards, above the standards and have their own characteristics, Guangdong University of Foreign studies further strengthens the characteristics and advantages of its specialties in accordance with the needs of social development, promotes the modernization by informationization and the construction of specialties by internationalization. We should seek to build a high-level international e-commerce talent training base in South China, and to form a practical system cultivating innovative talents and as a leading exemplary base.

\section{A. Strengthening the Construction of Practical Course System}

We should establish a practical teaching module suiting the basic courses, core courses and professional development courses of E-commerce and incorporate them into the implementation of the teaching plan. In 2015, the college redesigned the practical teaching module in the teaching plan of e-commerce specialty according to the requirements of the school's educational administration department and increased the applied and practical courses. At the same time, embedded semester teaching plan each semester added two weeks' intense practice training to every semester and therefore has formed into a practical teaching system with appropriate flexibility.

\section{B. Creating New Practical Education Environment}

The global procurement and cargo transportation have wide coverage, complex business processes and operation links, high operational risks and difficulty for students to practice in enterprises, we have formed a scientific curriculum and practical teaching content on the basis of existing practical teaching conditions. Until now, we have already had a practical teaching system of the virtual environment in school based on information environment; employee orientation and ability cultivation (see Table I.)

TABLE I. VIRTUAL ENVIRONMENT TRAINING PRACTICE SYSTEM

\begin{tabular}{|l|l|l|}
\hline No. & \multicolumn{1}{|c|}{ Laboratory description } & \multicolumn{1}{c|}{ Experimental program } \\
\hline 1 & Stereoscopic Warehouse and Electronic Label Warehouse & Automatic Warehousing Operation and Electronic Picking Experiment \\
\hline 2 & Pos systematic laboratory & Design and Operation of Retail Terminal Business System \\
\hline 3 & E-commerce Laboratory & $\begin{array}{l}\text { Business Process of Warehousing, Transportation, Distribution, Purchasing, Supply Chain } \\
\text { and International Freight Forwarder }\end{array}$ \\
\hline
\end{tabular}




\begin{tabular}{|l|l|l|}
\hline \multicolumn{2}{|l|}{ Cont. to TABLE I. } \\
\hline 4 & ERP laboratory & $\begin{array}{l}\text { ERP production management system experiment, ERP financial management system } \\
\text { experiment, ERP supply chain management system experiment }\end{array}$ \\
\hline 5 & Supply chain sand table systematic laboratory & Supply chain operational mock experience. \\
\hline 6 & $\begin{array}{l}\text { "Creating Business" Experiment of e-business laboratory } \\
\text { (handwork) }\end{array}$ & Business operation mock experience. \\
\hline 7 & Simulation laboratory & Simulation experiment of the e-commerce system \\
\hline 8 & Business negotiation laboratory & Panoramic simulation experiment of business negotiation \\
\hline
\end{tabular}

With the progress of technology and the development of the times, some hardware and software systems have not adapted to the practical teaching requirements of e-commerce major, and need to be upgraded and replaced. Therefore, we will develop and construct the following new training environment in collaboration with the superior resources of schools, enterprises, industries and government departments:

Item intelligence traces laboratory. We should carry out information technology and application experiments, such as cargo tracking, identification, query, information collection and management; we should enhance students' comprehensive ability to use modern information technology which can improve the level of e-commerce management.

We should provide a virtual practice teaching laboratory for e-commerce major students. In collaboration with the practice base, we will create a visualized e-commerce laboratory that can transmit information in real-time, and try to use the new generation of information technology environment to solve the new way of e-commerce business training environment based on globalization.

\section{Strengthening the Guidance of Students' Extracurricular Practice Activities}

Extracurricular practical activities in the second classroom without credit are an indispensable part of the practical teaching system. The E-commerce major of our university takes the student organization "E-commerce Association" as the core, and carries out a series of second classroom activities for undergraduates. (See Table II)

TABLE II. SECOND CLASSROOM FOR UNDERGRADUATES

\begin{tabular}{|c|l|l|}
\hline No & \multicolumn{1}{|c|}{ Activity name } & \multicolumn{1}{|c|}{ Contents and outcome } \\
\hline 1 & $\begin{array}{l}\text { Holiday internship } \\
\text { activities }\end{array}$ & $\begin{array}{l}\text { to gain work experience and improve their } \\
\text { ability to adapt to society }\end{array}$ \\
\hline 2 & $\begin{array}{l}\text { Scientific research } \\
\text { assistant activities }\end{array}$ & $\begin{array}{l}\text { Students participate in teachers' scientific } \\
\text { research projects, cultivate students' ability to } \\
\text { analyze and solve problems and constantly } \\
\text { acquire new knowledge. }\end{array}$ \\
\hline 3 & $\begin{array}{l}\text { E-Commerce } \\
\text { Presentation } \\
\text { Competition }\end{array}$ & $\begin{array}{l}\text { Successfully held for seven consecutive } \\
\text { years, fosters the ability to express, } \\
\text { communicate and conceptualize. }\end{array}$ \\
\hline 4 & $\begin{array}{l}\text { E-Commerce design } \\
\text { Competition }\end{array}$ & $\begin{array}{l}\text { Trains research ability, E-commerce system } \\
\text { analysis and design ability, Writing and } \\
\text { expression ability }\end{array}$ \\
\hline 5 & $\begin{array}{l}\text { College } \\
\text { entrepreneurship } \\
\text { contest }\end{array}$ & $\begin{array}{l}\text { Cultivates students' market keen ability, } \\
\text { decision-making ability and competitive } \\
\text { consciousness. } \\
\text { Participated in the "Challenge Cup" college } \\
\text { entrepreneurship contest and won many } \\
\text { awards }\end{array}$ \\
\hline
\end{tabular}

In the second class activities, it is very welcomed by students, but due to the lack of teachers' guidance in some practical activities, the activities are not carried out in-depth. Therefore, we invite a group of dominant scholars and practical experts at home and abroad as visiting professors and invite them to introduce frontier theories and hot practical issues regularly, so as to stimulate students' enthusiasm for learning.

\section{Building an Internationalized Practice Platform}

We should actively carry out the third classroom activities abroad, make full use of the open policy and the advantages of international resources of schools, establish international cooperation with overseas enterprises and institutions, and expand students' internship space in both overseas enterprises and institutions. In practice, we need to explore relevant policies and systems, encourage students to engage in future career-related internships during school and broad, and even allows them to practice in the form of off-the-job training, so as to enable students to be espoused in internationalized practical work as early as possible and obtain relevant professional qualifications, and provides training support for qualified students abroad. We should establish internship channels abroad for students to encourage them to practice in overseas enterprises, so as to cultivate international e-commerce talents with international or training background.

\section{CONCLUSiON}

The national standard of e-commerce is the basic standard for professional construction. On the basis of this standard, colleges and universities can formulate the practical goals and improve practical teaching contents according to their own disciplinary advantages, school-running characteristics and regional needs, and in accordance with the idea of practical teaching objectives, improving practical teaching content and building a systematic practical teaching platform. The ecommerce major can cultivate application-oriented professionals and become an innovative major for Internet business employment and entrepreneurship.

\section{REFERENCES}

[1] Website of the Ministry of Education of the People's Republic of China http://www.moe.gov.cn/(In Chinese)

[2] Zhang Xingwang, Chen Xiaoling. Construction and Practice of Practical Teaching System of "245" Mode for Applied Undergraduates [J]. Journal of Lanzhou Institute of Education, 2010, 26 (05): 130-132. (In Chinese)

[3] Yan Wei, et al. Sustainable Development of National Experimental Teaching Demonstration Center [J]. Laboratory Research and Exploration, 2016 (10): 151-154. (In Chinese) 
[4] Pan Haihan, Zhao Yuru, Xu Shihao. Reflections on the Reconstruction of Experimental Teaching Demonstration Center [J]. Research on Higher Engineering Education, 2015 (4): 189-192. (In Chinese)

[5] Wu Gang, Gao Liucai. Multidimensional Interpretation of the Connotation of Practical Education in Colleges and Universities [J]. Educational Exploration, 2013 (8): 13-15. (In Chinese)

[6] Gao Dongfeng. Requirements, Thoughts and Paths of Experimental Teaching Reform in Colleges and Universities in the Information Age [J]. China Higher Education Research, 2018 (4): 97-100. (In Chinese) 